\title{
KONTEKS DALAM STUDI LINGUISTIK PRAGMATIK
}

\author{
Akhmad Saifudin \\ akhmad.saifudin@dsn.dinus.ac.id \\ Universitas Dian Nuswantoro
}

\begin{abstract}
This paper tries to provide an understanding of the context in pragmatic linguistic studies. Pragmatic linguistic studies are known as branches of linguistics which discuss the meaning of speech based on context. In this paper the context is understood as a conceptual framework about everything that is used as a reference in speaking or understanding speech. Context is classified into two types, namely linguistic and nonlinguistic. Linguistic contexts are contexts whose references are contained in previous speeches and nonlinguistic contexts are not found in speech or outside of language. The nonlinguistic context can be divided into four types, namely physical, psychological, social, and shared knowledge contexts.
\end{abstract}

Keywords: Pragmatics, Context, Text, Meaning, shared knowledge

Ketika kita menanyakan maksud atau makna suatu tuturan kepada seseorang, seringkali tidak langsung memperoleh jawaban, melainkan justru mendapat pertanyaan balik, misalnya "konteksnya apa dulu nih?" Nah, dari respon ini berarti kita dapat menyimpulkan bahwa makna atau maksud suatu bahasa atau tuturan ditentukan oleh konteks. Lalu, apa sebenarnya yang dimaksud dengan konteks? Mengapa makna harus ditentukan dengan konteks? Apakah kita tidak dapat memaknai tuturan atau bahasa tanpa konteks? Untuk menjawab pertanyaan-pertanyaan tersebut mari kita perhatikan dua ilustrasi berikut ini.

(1) Di sebuah toko yang menjual papan nama terdapat papan nama yang bertuliskan "KASIR" tertempel di dinding tempat memajang contohcontoh hasil karya toko tersebut. Papan nama yang bertuliskan "KASIR" 
Akhmad Saifudin, Konteks dalam Studi Linguistik Pragmatik

juga terdapat di salah satu meja tempat di mana pembeli membayar barang yang dibelinya.

(2) Ibu : Besok jadi berangkat ke Dieng?

Anak : Tenang Bu, sudah ada kok jaket tebalnya.

Ibu : Syukurlah kalau begitu.

Mari kita bahas bagaimana memaknai kedua ilustrasi di atas. Di ilustrasi (1) makna yang dibahas adalah "KASIR". Kata tersebut terdapat di dua tempat, yakni di dinding dan di atas meja. Apakah maknanya sama atau berbeda? Apakah posisi di dinding dan di meja dapat menentukan maknanya? Apakah makna "KASIR" dapat diketahui dengan mengabaikan lokasi yang di dinding atau di meja?

Untuk memaknai "KASIR" sebenarnya dapat diketahui dengan mudah dengan cara mencari arti kata tersebut di dalam kamus (apabila memang belum memahami arti "KASIR"). Dengan cara ini berarti sudah menjawab pertanyaan yang terakhir di atas bahwa makna kata tersebut dapat diketahui tanpa memperhatikan lokasi di mana kata tersebut berada. Apakah itu sudah cukup? Lalu kenapa orang-orang hanya melihat-lihat saja kata "KASIR" yang ada di dinding? Kenapa orang-orang membayar di "KASIR" yang ada di meja? Berarti, makna keduanya berbeda, dan yang membedakan adalah lokasinya. Lokasi yang membedakan kedua makna dari kata yang sama, yakni "KASIR" inilah yang disebut konteks. "KASIR" yang berada di dinding memang ditujukan sebagai contoh untuk dipamerkan agar orang tertarik memesan papan nama di toko tersebut. Dalam hal ini sebenarnya yang dipentingkan bukan konten (kata yang tertulis), melainkan objeknya yakni papan nama. Sementara "KASIR" yang berada di atas meja memang dibuat untuk tujuan berkomunikasi dengan pengunjung toko bahwa di situlah kasirnya dan kalau membeli barang di toko tersebut maka bayarlah di tempat yang ada papan nama "KASIR"nya. 
Kemudian mari kita lihat di ilustrasi (2). Di sini terdapat percakapan antara Ibu dan anaknya. Si ibu menanyakan konfirmasi apakah anaknya jadi berangkat ke Dieng. Si anak bukannya menjawab ya atau tidak malah menjawab dengan jawaban yang tidak ada relevansinya dengan pertanyaannya. Namun jika melihat respon dari si Ibu ternyata jawaban anaknya tersebut tidak bermasalah dan dipahami oleh Ibu. Mengapa si Ibu dapat memahami jawaban si anak? Itu adalah karena si Ibu sudah memahami konteksnya. Dari percakapan tersebut, dapat diketahui bahwa itu bukan percakapan pertama yang membahas tema kepergian anaknya. Ada kemungkinan dalam percakapan sebelumnya si anak memberi tahu ibunya tentang rencana kepergian ke Dieng. Oleh karena si ibu sudah mengetahui bahwa daerah Dieng itu dingin maka ia menyarankan agar membawa jaket tebal yang pada saat itu belum dimiliki oleh anaknya. Sehingga pada percakapan ilustrasi (2) pertanyaan ibu tentang jadi tidaknya pergi ke Dieng dimaknai anaknya sebagai kekhawatiran ibunya karena sebelumnya belum tersedia jaket tebal.

Dari kedua ilustrasi yang sudah dicontohkan kita dapat melihat bahwa konteks sangat penting dalam memahami maksud bahasa atau tuturan dalam sebuah komunikasi. Makna memang dapat dipahami tanpa menggunakan konteks seperti dalam ilustrasi (1), namun ketika bahasa digunakan sebagai alat komunikasi, konteks mau tidak mau harus dijadikan bagian penting dalam memahami makna.

\section{Studi Linguistik Pragmatik}

Disiplin ilmu linguistik yang menggunakan konteks sebagai alat utama untuk memahami makna adalah pragmatik. Menurut Levinson (1983, p. 21) pragmatics is the study of the relations between language and context that are basic to an account of language understanding 'Pragmatik adalah kajian tentang hubungan antara bahasa dan konteks yang menjadi dasar pertimbangan untuk memahami bahasa'. Levinson juga membuat beberapa konsep lain tentang pragmatik, yakni pragmatics is the study of those relations between language and 
Akhmad Saifudin, Konteks dalam Studi Linguistik Pragmatik

context that are grammaticalized, or encoded in the structure of language 'Pragmatik adalah kajian tentang hubungan antara bahasa dan konteks yang digramatikalisasi atau dikodekan di dalam struktur bahasa' dan Pragmatics is the study of the ability of language users to pair sentences with the context in which they would be appropriate 'Pragmatik adalah kajian tentang kemampuan pengguna bahasa untuk menyesuaikan kalimat dengan konteks sehingga dapat digunakan dengan tepat'. Kemudian beberapa pengertian pragmatik yang lain, pragmatik adalah studi tentang makna dalam hubungannya dengan situasi percakapan (Leech, 1983; Mey, 2001).

Pada intinya nosi penting dalam pragmatik adalah pengguna bahasa, penggunaan bahasa, dan konteks. Dengan kata lain jika dijabarkan adalah pragmatik mempelajari bagaimana orang menggunakan bahasa dalam suatu konteks tertentu. Pragmatik mengkaji maksud penutur dalam tuturan yang digunakan, bukan mengkaji makna tuturan atau kalimat (Saifudin, 2005). Mengkaji makna tuturan atau kalimat dibutuhkan pengetahuan akan tata bahasa, sementara dalam mengkaji maksud penutur dibutuhkan pemahaman bersama yang didasarkan atas pengetahuan atau pengalaman yang telah sama-sama diketahui yang melatari penuturan.

Dalam pragmatik tuturan (atau dapat disebut juga dengan teks) menjadi tidak bermakna tanpa konteks. Teks tidak bermakna tanpa konteks. Teks yang dimaksud di sini bukan saja bermakna wacana tulis, namun mencakup konsep yang lebih luas, yakni tuturan baik tulis maupun lisan dalam suatu wacana tertentu. Seperti dalam contoh ilustrasi (1), teks "KASIR" yang tertempel di dinding tidak mempunyai makna karena tidak menunjukkan maksud apa-apa. Namun, teks "KASIR" yang berada di atas meja mempunyai makna karena ada konteksnya dan ditulis untuk tujuan komunikasi. Konteksnya apa? Yakni konteks pengetahuan bersama yang terbagi atau dimiliki oeh peserta tutur bahwa di toko disediakan tempat pembayaran yang dinamakan kasir. Konteks ini dilengkapi dengan konteks fisik berupa seperangkat alat, seperti penghitung uang, komputer, dan printer yang diletakkan di meja kasir. 


\section{Memahami Makna Konteks}

Seperti sudah dipaparkan dalam bagian pragmatik, konteks memiliki peran yang sangat signifikan dalam memahami maksud tuturan atau teks. Lalu apakah yang disebut konteks? Menurut pandangan penulis, konteks sangat berpengaruh bagi penutur dalam memproduksi teks dan sangat berpengaruh pula bagi mitra tutur, pendengar, atau pun pembaca dalam memahami teks. Ketika penutur atau pembuat teks memproduksi teks, ia akan memikirkan segala sesuatu yang akan dijadikan rujukan teks. Ia akan memikirkan teks-teks yang ada sebelumnya; siapa yang diajak bertutur; atau siapa pembacanya. Ia akan mempertimbangkan referensi-referensi apa yang dapat dipakai yang menurut pendapatnya petutur juga mempunyai akses atau pengetahuan tentang referensi tersebut, sehingga teks yang dibuat dapat dipahami oleh mitra tuturnya. Sebagai contoh ketika si A berbicara dengan si B, maka A akan melihat hubungan kedekatan, hubungan vertikal, dan tingkat formalitas, untuk menentukan ragam bahasa yang nanti akan digunakan. Ia juga akan melihat di mana tempat, waktu, pengetahuan yang dimiliki mitra tuturnya agar teks yang diproduksi dapat dipahami oleh mitra tuturnya. Dengan demikian dapat dikatakan bahwa konteks itu sangat kompleks, bukan hanya masalah tempat dan waktu, lebih dari mencakup sejumlah pengetahuan yang diketahui bersama antara penutur dan mitra tutur.

Dari hasil paparan tentang konteks, maka dapat dikatakan bahwa konteks adalah kerangka konseptual tentang segala sesuatu yang dijadikan referensi dalam bertutur ataupun memahami maksud tuturan. Kerangka yang dimaksud di sini adalah seperangkat peranan dan hubungan yang menjadi bagian dari pembentuk makna. Konseptual berarti ia berada di dalam pikiran manusia dan dijadikan sebagai pemahaman dari hasil olah pikir, pengalaman, ataupun hasil persepsi dari indera manusia. Apabila divisualkan maka gambaran konteks adalah sebagai berikut. 
Akhmad Saifudin, Konteks dalam Studi Linguistik Pragmatik

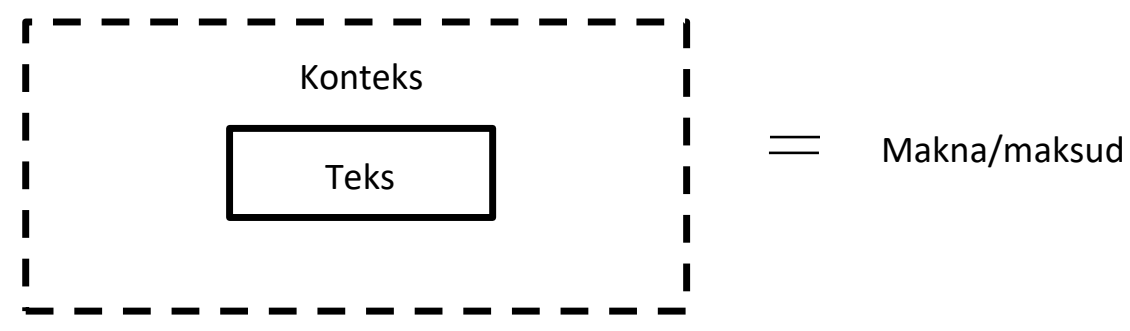

Dari visualisasi tersebut tampak bahwa makna atau maksud teks diperoleh melalui gabungan antara teks dan konteks. Konteks digambarkan dalam kotak yang lebih besar karena memang konteks lebih luas dari teks. Kotak dengan garis putus-putus menggambarkan bahwa konteks tidak terdapat dalam teks, tidak tertulis atau terucap dalam teks.

\section{Jenis-Jenis Konteks}

Dari pemaparan tentang konsep konteks, dapat diketahui bahwa cakupan konteks sangat kompleks karena berkenaan dengan pikiran manusia yang juga sangat kompleks. Bukan perkara yang mudah bagi penulis untuk mengkalisfikasikan konteks berdasarkan jenisnya. Namun, berdasarkan konsep yang dipaparkan di bagian sebelumnya, setidaknya konteks dapat dibagi menjadi dua, yakni konteks linguistik dan nonlinguistik. Konteks linguistik adalah referensi yang diperoleh dari teks atau tuturan yang sudah dituturkan sebelumnya. Sebagai contoh adalah tuturan "Apa yang Kamu katakan itu telah membuat Ibumu kecewa". Referensi kata itu diperoleh dari tuturan yang sudah dituturkan mitra tutur sebelumnya.

Jenis konteks nonlinguistik menyangkut referensi yang lebih luas karena referensinya bisa apa pun di luar bahasa yang melatari terjadinya teks. Jenis-jenis konteks nonlinguistik tersebut adalah sebagai berikut.

a) Konteks fisik 
Konteks fisik berhubungan dengan di mana komunikasi terjadi, objek apa saja yang ada, dan aktifitas apa yang terjadi. Dengan kata lain konteks fisik adalah referensi yang dapat dipersepsi langsung oleh indera manusia karena hadir di sekitar pertuturan. Referensi tersebut dapat diketahui oleh peserta tutur dengan cara melihat, mendengar, mencium, merasakan, menyentuh, dan lain-lain.

Contoh:

- "Kita ketemu di sini ya, nanti malam pukul tujuh." (referensi tempat dan waktu).

- "Itu milikku ya." (referensi objek yang ditunjuk).

b) Konteks psikologis

Konteks psikologis berkaitan dengan kondisi perasaan peserta tutur pada saat tuturan digunakan dalam komunikasi. Perasaan bahagia, senang, marah, kecewa, dan sedih akan berpengaruh pada tuturan yang dituturkan. Pengetahuan akan kondisi psikologis peserta tutur sangat penting dimiliki agar dapat memahami, menjelaskan, dan memprediksi tuturan.

Contoh:

- “Luar biasa!" (Maknanya sangat tergantung pada perasaan penuturnya).

c) Konteks sosial

Konteks sosial berkaitan dengan atribut-atribut sosial peserta tutur dan setting pertuturan (formalitas). Hasil dari pemahaman akan konteks sosial adalah penggunaan register yang sesuai pemakaian, atau pun pilihan-pilihan bahasa yang tepat digunakan berdasarkan pemakaiannya di masyarakat. Pilihan bahasa atau register didasari atas referensi hubungan vertikal (tinggi rendah status) dan horisontal (tingkat keakraban) peserta tutur, serta formalitas. Dua hal yang pertama adalah pertimbangan siapa yang berbicara, siapa yang diajak berbicara, siapa yang hadir, dan siapa pelaku aktifitasnya. Kemudian yang terakhir, yakni formalitas (berkaitan dengan tata cara dan peraturan) 
Akhmad Saifudin, Konteks dalam Studi Linguistik Pragmatik

adalah pertimbangan tempat, peristiwa, dan topik pertuturan. Terdapat perbedaan antara pertuturan di tempat ibadah dan di pasar; di rapat dan saat mengobrol di kantin; atau pun perbedaan tuturan antara topik serius dan tidak serius.

Contoh:

- “Apakah Bapak berkenan hadir dalam acara pertunangan kami?” (sopan + formal)

- “Bisa nggak lu datang?”(tidak sopan/akrab + tidak formal)

d) Konteks pengetahuan bersama

Konteks pengetahuan bersama ini oleh Yan Huang disebut sebagai ' $a$ set of background assumptions shared by the speaker and the addressee.'(2007, p. 14) dan oleh Stalnaker disebut common ground atau latar belakang pengetahuan bersama (2002). Konteks pengetahuan bersama inilah yang sebenarnya menjadi inti dari konteks dalam pragmatik. Konteks ini diperoleh melalui pengalaman yang kemudian tersimpan dalam pikiran (memori) manusia. Melalui pengalaman ini, petutur dapat membuat tuturan yang dapat dimengerti maksudnya oleh mitra tuturnya. Sebaliknya, mitra tutur juga dapat mengerti maksud penutur karena mempunyai pengalaman atau pengetahuan yang sama. Dengan demikian, pengetahuan akan latar belakang yang dipertuturkan harus dimiliki bersama antara penutur dan mitra tutur, jika hanya dimiliki oleh salah satu pihak saja tidak akan berguna dalam pemahaman maksud tuturan.

Contoh:

- Bapak: “ini jam berapa?"

Ibu: "anak-anak sudah tidur kok Pak."

Percakapan antara bapak dan ibu ini adalah contoh yang dapat menjelaskan sumbangan konteks pengetahuan bersama. Meskipun jawaban ibu nampak tidak ada relevansinya dengan pertanyaan bapak, keduanya memiliki pengetahuan bersama akan maksud tuturannya masingmasing. Ibu memahami maksud pertanyaan bapak sebagai pertanyaan 
untuk mengingatkan apakah anak-anak sudah tidur karena sudah waktunya tidur (sebelumnya sudah ada kesepakatan di keluarga tentang jam tidur anak-anak).

\section{Simpulan}

Simpulan dari tulisan ini menegaskan kembali pentingnya konteks dalam bertutur (memproduksi teks) dan memahami maksud tuturan. Inilah sebenarnya inti dari studi pragmatik, yakni pemahaman maksud tuturan (teks) melalui konteks. Tuturan mempunyai makna jika disertai konteks. Tentu saja konteks yang dimaksud adalah konteks yang dipahami bersama antara penutur dan mitra tuturnya. Konteks berada di dalam pikiran manusia, berisi tentang informasi atau pengetahuan yang menjadi dasar dalam bertutur atau memahami tuturan. Meskipun konteks dapat diklasifikasikan dalam beberapa jenis, yakni konteks linguistik dan nonlinguistik (fisik, psikologis, sosial, dan pengetahuan bersama), konteks pengetahuan bersamalah yang menjadi perhatian utama dalam studi linguistik pragmatik. Dengan adanya kesamaan pengetahuan yang melatari tuturan di antara peserta tutur, bahasa dapat dituturkan dalam berbagai bentuk, namun tetap dapat dimengerti maksudnya.

\section{REFERENSI}

Huang, Y. (2007). Pragmatics. Oxford - New York: Oxford University Press.

Leech, G. N. (1983). Principles of Pragmatics. London and New York: Longman.

Levinson, S. (1983). Pragmatics. Cambridge: Cambridge University Press.

Mey, J. L. (2001). Pragmatics an introduction. Massachusetts: Blackwell.

Saifudin, A. (2005). Faktor Sosial Budaya dan Kesopanan Orang Jepang dalam Pengungkapan Tindak Tutur Terima Kasih pada Skenario Drama Televisi Beautiful Life Karya Kitagawa Eriko. Universitas Indonesia. https://doi.org/10.13140/RG.2.2.13134.56643 
Akhmad Saifudin, Konteks dalam Studi Linguistik Pragmatik

Stalnaker, R. (2002). Common ground. In Linguistics and Philosophy (pp. 701721). Netherlands: Kluwer Academic Publishers. Retrieved from http://williamstarr.net/teaching/speech_acts/Stalnaker-2002Common_Ground.pdf 